\title{
Racimo, la novela rizoma de Diego Zúñiga*
}

\author{
Patricia Angélica Péndola Ramírez** \\ Patricio Alfonso Landaeta Mardones***
}

\begin{abstract}
Resumen
Este artículo propone una lectura de la novela Racimo (2014) de Diego Zúñiga desde los postulados teóricos desarrollados por Gilles Deleuze y Félix Guattari. El objetivo de la propuesta es indagar los alcances del juego de palabras "racimo-rizoma" en la construcción y disposición de acontecimientos narrados, para evidenciar que la novela funciona como rizoma. El montaje de elementos dispares rompe el orden convencional y traza variadas líneas de fuga que transgreden la verdad instituida. Se aborda además el imaginario del desierto y del mar chileno, a partir de las definiciones conceptuales entregadas por Jean Jacques Wunnenburger.
\end{abstract}

Palabras clave: Rizoma, desterritorialización, líneas de fuga, Racimo, Diego Zúñiga.

\section{Racimo, The Novel Rhizome by Diego Zúñiga}

\begin{abstract}
This article proposes a reading of the novel Racimo (2014) by Diego Zúñiga from the theoretical framework developed by Gilles Deleuze and Felix Guattari. The purpose of this proposal is to investigate the scope of the pun "racimo-rhizome" in the construction and arrangement of the events narrated to show that the novel works as a rhizome. The assembly of dissimilar elements breaks the conventional order and traces varied lines of flight that transgress the instituted truth. Also, the imaginary of the desert and the Chilean sea is approached, starting from the conceptual definitions given by Jean Jacques Wunnenburger.
\end{abstract}

Keywords: Rhizome, Deterritorialization, Lines of flight, Racimo, Diego Zúñiga.

\footnotetext{
* $\quad$ Este trabajo es el resultado del Seminario de Estética del Discurso, del Doctorado en Literatura Hispanoamericana Contemporánea de la Universidad de Playa Ancha, impartido por el Dr. Patricio Alfonso Landaeta Mardones.

** Chilena. Profesora de Castellano. Magíster en Literatura Hispanoamericana, Pontificia Universidad Católida de Valparaíso. Doctoranda en Literatura Hispanoamericana Contemporánea de la Universidad de Playa Ancha, Valparaíso, Chile. patipen@gmail.com

*** Chileno. Doctor en Filosofía por la Pontificia Universidad Católica de Valparaíso y por la Université Paris VIII Vincennes-Saint-Denis. Doctor Europeo en Filosofía y Máster en Estudios Avanzados en Filosofía por la Universidad Complutense de Madrid, España. Investigador del Centro de Estudios Avanzados de la Universidad de Playa Ancha, Valparaíso, Chile. patricio.landaeta@upla.cl
} 


\section{Racimo, una novela rizoma}

Racimo (2014), la segunda novela del escritor chileno Diego Zúñiga (1987) aborda en su trama el caso real del secuestro, violación y homicidio de catorce mujeres, la gran mayoría menores de edad, cometidos en Alto Hospicio -Norte de Chile- por un asesino en serie, entre los años 1998 y 2001. La ficción, en tanto, ubica los crímenes entre 1994 y 2001 y recrea las semanas anteriores a la detención del sospechoso Miguel Ángel Paz Solís ${ }^{1}$, quien finalmente es procesado y condenado. La voz dominante es la tercera persona omnisciente, que cuenta los hechos desde la focalización del protagonista, Torres Leiva, un fotógrafo que se traslada a Iquique para trabajar en un diario local. El narrador -heterodiegético- que enuncia en presente e incluso adelanta acontecimientos, se alterna con los relatos en primera persona de otros sujetos. Uno de ellos, García -compañero de labores del primero- es quien informa de las circunstancias y detalles de las desapariciones, entregando datos sobre la vida de tres de las víctimas y sus familias. La trama abarca también parte del proceso de la investigación. El desenlace, ubicado alrededor de diez años después de los sucesos que inician la novela, abre una nueva interrogante frente a los crímenes. La narración está dividida en cinco capítulos, de los cuales el cuarto destaca por su brevedad.

Racimo cuenta con escasa crítica. Tanto en reseñas de corte periodístico como en artículos académicos, el texto es abordado desde la perspectiva de la violencia, elemento fundamental del relato; entre ellos podemos nombrar los artículos de Fermín Rodríguez y de Daniuska González González y Alexis Candia-Cáceres. Por lo anterior, también se la vincula con la obra de Roberto Bolaño (1953-2003), dadas sus coincidencias temáticas como espaciales. Dicho de otro modo, los hechos ficcionalizados por ambos autores tienen referentes reales similares. Ambos abordan femicidios en espacios desérticos, ya sea en la ficticia ciudad mexicana de Santa Teresa -la que alude implícitamente a Ciudad Juárez, México-, en las novelas 2066 (2004) y Los sinsabores del verdadero policía (2011), del fallecido escritor chileno, como en Alto Hospicio y sus alrededores, escenario donde Zúñiga reelabora los crímenes desde la ficción. 
El crítico literario Fermín Rodríguez (2016) interpreta las similitudes entre los textos de los mencionados novelistas en un estudio breve que establece algunas comparaciones entre las producciones literarias de los dos chilenos. En su propuesta, Rodríguez plantea que "las mujeres de la literatura del siglo XXI, [...] desaparecen y mueren en el aire ominoso de novelas saturadas de una violencia inminente y difusa que lo envuelve todo, donde se violan derechos y mujeres" (43).

Desde similar perspectiva, Daniuska González González y Alexis Candia-Cáceres (2017) abordan Racimo en un artículo académico cuya premisa -enmarcada precisamente en el estudio de la violencia que se instaura como modo y consecuencia de la acelerada industrializaciónpropone que la novela de Zúñiga se ubica dentro de las narrativas que:

[C]onfiguran una "geografía del horror" entendida como una multiplicidad de espacios que, al proyectarlos un individuo sobre la sociedad, crean un imaginario de lo que se percibe como el mal, un dominio que coloca bajo sospecha y que se confina como lo Otro. Entre estos espacios de representación se halla el vacío, la abyección, la tortura, la ruina, la catástrofe. (81)

Los estudios anteriores en torno a Racimo analizan la novela como una narrativa que al indagar en torno a la violencia comparte, por lo mismo, algunos rasgos del relato policial, como los crímenes irresueltos, la búsqueda de culpables y la impunidad.

En cuanto al escenario de los crímenes, Waldman Mitnick (2016) problematiza el paisaje del desierto y los sujetos que circulan por este espacio: "La metáfora del desierto entraña una fabulación en la que no existe identidad fija ni destino final. La naturaleza fluida del desierto nunca coincide del todo con la nación ni con el Estado. Es el espacio sin límites donde todo es posible [...]" (6o). Las características a las que apunta Waldman son las que le permiten hacer una referencia directa a la novela de Zúñiga, pues puntualiza respecto al territorio -el Norte Grande de Chile- que: "el desierto de Atacama también fue el espacio de desaparición de numerosos [sic] jóvenes adolescentes de Alto Hospicio" (64), para agregar que se trata de una zona: “[e]mpobrecida y degradada”, "atravesada de punta a punta por redes nacionales y transnacionales de corrupción, narcotráfico y crimen organizado".

Respecto del mar chileno, la novela enfatiza el imaginario en torno al Pacífico desde la perspectiva que lo vincula a la muerte. El océano es la 
amenaza de la ola que todo lo arrasa; es la tumba de los desaparecidos de la dictadura del general Pinochet; es el medio elegido para el envío de las bombas de racimo hacia Irak.

El presente artículo, sin descartar los abordajes precedentes, propone una lectura de la novela Racimo desde algunos de los postulados teóricos desarrollados por Gilles Deleuze y Félix Guattari en su publicación Mil mesetas, capitalismo y esquizofrenia (2004). El objetivo de esta propuesta es indagar los alcances del juego de palabras "racimo-rizoma" en la construcción y disposición de los acontecimientos narrados. A través de este relato rizomático, la novela propone que existen otras versiones distintas a la oficial, que han abordado los femicidios ocurridos en Alto Hospicio. Asimismo, se problematiza también el imaginario del desierto y del mar chileno, este último a partir de las definiciones conceptuales entregadas por Jean Jacques Wunnenburger (2000), ya que como elementos constitutivos del relato, no se limitan a construir un telón de fondo para los hechos; al contrario, desierto y mar son parte fundamental del rizoma, de la multiplicidad que constituye los hechos ficcionalizados.

Racimo deja en el desenlace un misterio irresuelto, pero además a lo largo del desarrollo va incorporando situaciones y recuerdos que finalmente se transforman en enigmas sin solución. De este modo, la novela sigue más de una línea narrativa, incorporando varias voces que enuncian junto a la principal, con lo cual se presentan líneas de fuga que enlazan lo narrado con otros hechos de realidad histórica nacional ocurridos durante la dictadura cívico-militar encabezada por el General Augusto Pinochet (1973-1990). Es decir, la disposición del relato obedece a un montaje de elementos dispares que funciona como rizoma, en cuanto rompe el orden convencional -dar cuenta de los acontecimientos que rodean el crimen y dilucidan el caso- para trazar variadas líneas de fuga que contravienen la verdad instituida, forzándonos a pensar de otro modo (Landaeta 182). El suceso referido y ficcionalizado aparece atravesado, horadado por estos hechos que de manera inesperada son incorporados para abrir la puerta hacia otras historias y otras lecturas.

En la perspectiva de Deleuze y Guatari (2004), el mar y el desierto son espacios lisos, no estriados, vale decir, espacios abiertos al afuera, compuestos de rutas y recorridos nunca acabados, a diferencia de los espacios estriados, cerrados por definición al circunscribir un interior (370). Desierto y mar son justamente las dos zonas geográficas de mayor significación en Racimo. Si con la imagen del desierto se erige el retrato de una vastedad 
difícilmente territorializable por el Estado, con la del mar se hace referencia al espacio ambiguo que, como se verá, está presente tanto en el imaginario de la creación del Estado-nación, como en la crisis del mismo, al ser convertido por la dictadura cívico-militar en lugar de olvido y de degradación. No obstante, la similitud va más allá de las locaciones en que ocurren los acontecimientos de la novela, puesto que funcionan también como "un espacio liso heterogéneo, [...] unido a un tipo muy particular de multiplicidades" (376). La narración, en su propia escritura, deviene una multiplicidad de relatos distintos de la trama central, que en otro tipo de relato marcaría la coincidencia de una línea temporal con una línea argumentativa con efecto de progresión. En efecto, la trama en la novela de Zúñiga se dispara en distintas direcciones, evitando el camino recto de la historia lineal. En ese sentido, es posible aludir a una de las primeras notas del concepto de rizoma, la multiplicidad: "las multiplicidades no métricas, acentradas, rizomáticas, que ocupan el espacio sin 'medirlo', y que solo se pueden 'explorar caminando sobre ellas"' (376). El relato, en tanto unión no totalizada de multiplicidades, emprende un viaje sin un destino definido, ni desenlace que aclare o cierre los enigmas; renuncia a interpretar los hechos, se limita a recoger los fragmentos de esas historias que van apareciendo. Se trata, pues, de un montaje de elementos dispares que configura a la novela como un rizoma. Ahora bien, ¿Qué tiene de singular este montaje?

Una narración tradicionalmente consiste en contar o intentar develar un hecho en su verdad, desde su origen hasta su desenlace, aun cuando el hecho referido comience in media res o in extrema res; aun cuando se empleen recursos tales como el flash back o el racconto. Todo ello, busca ordenar esquemática y lógicamente los acontecimientos, entregando un hilo conductor causal, que acompañe al lector a un desenlace determinado, o a un sentido prefijado, en suma, toda una estructura racional que asegura la verosimilitud del relato. En contraste, en Racimo se contraviene dicha práctica metódica, en tanto las voces que enuncian siguen las multiplicidades descentradas que surgen a medida que van apareciendo los acontecimientos, sin necesidad de organizarlas en un relato con sentido, sin establecer entre ellas jerarquía alguna. En efecto, dichas conexiones rizomáticas atentan contra la idea de un mundo ordenado y organizado por un logos, por una razón que viene a sellar la verdad o necesidad de los hechos que solo en apariencia son frutos del azar; al contrario, dan lugar a distintas líneas de fuga, de las cuales se analizan solo cinco en este artículo. 
El comienzo del relato presenta a Torres Leiva conduciendo su automóvil por el desierto en dirección a Iquique durante la madrugada. Una escolar le hace señas para que la lleve; él se detiene y la joven sube. Esta acción inicial se va impregnando de irrealidad a medida que transcurren las primeras páginas, la que aumenta cuando Torres Leiva ve a otra escolar en la carretera y luego observa por el espejo retrovisor cómo ella se desmaya. El fotógrafo, en lugar de continuar su recorrido, detiene el auto y va a prestarle su auxilio. No obstante, al acercarse, comprueba que se trata de un enorme perro herido. A consecuencia de ello, la joven que recogió en el camino abandona el auto y se aleja por el desierto.

Los sucesos narrados en las primeras páginas parecen espejismos o imágenes de lo que vendrá, pues efectivamente, la reiteración de la escena de la escolar en la carretera que cae a la orilla de la berma será el acontecimiento que vincule a Torres Leiva con las desapariciones de Alto Hospicio. Días después del hecho referido, el fotógrafo, en compañía de su compañero de labores García, vuelve a vivir una experiencia similar; pero esta vez, sí se trata de una chica que ha caído a orillas de la carretera. Ambos hombres la socorren y la llevan al hospital. Más adelante se sabrá la identidad de la muchacha, se trata de Ximena, una de las jóvenes desaparecidas, personaje clave en la trama ya que no solo sobrevivió, sino que estuvo dos años extraviada. La joven, que inicialmente se encuentra en un estado de coma profundo, finalmente despierta, revela lo sucedido y ayuda a identificar al asesino.

\section{Cómo se narra y quiénes narran}

La novela da cuenta de un suceso con base en la realidad, en esa medida ficcionaliza un hecho renunciando a ofrecer una verdad concluyente; lo abre para proponer otras versiones, con lo cual el relato aúna elementos en una trama con el fin de desterritorializar aquello que se tiene por verdad. Por ello se dice que todo rizoma -y Racimo funciona como tal- "comprende líneas de segmentaridad según las cuales está estratificado, territorializado, organizado, significado, atribuido, etc; pero también líneas de desterritorialización según las cuales se escapa sin cesar" (Deleuze y Guattari 15). Esto se comprende más claramente cuando se advierte que Zúñiga ofrece otra versión distinta de la oficial, puesta como una lápida sobre los hechos, y la discute, la confronta; visualiza y propone líneas de fuga al acontecimiento histórico que inspira 
la trama, lo descentra, mostrando como superflua la necesidad que se arroga la verdad oficial. La versión dada a conocer por la prensa, recoge la sentencia judicial que culpa y condena a un solo hombre, Julio Pérez Silva, como el autor material de los asesinatos en serie. La novela de Zúñiga, en tanto, también señala a un solo sujeto como responsable de los crímenes, Miguel Ángel Solís. En esa medida, la novela ficcionaliza y problematiza acontecimientos que en algún momento hicieron noticia para luego hundirse en el olvido. Sin embargo, la narración rizomática va a sugerir otras causas que expliquen la desaparición de las niñas, las que no habrían sido asesinadas, sino secuestradas por una red de prostitución infantil de carácter internacional. Por tanto, vuelve a traer a la luz los acontecimientos una vez que han perdido su carácter de novedad, y los convierte en problema precisamente con el fin de mostrar su carácter de incógnitas que parecen iluminarse al conectarse con otros hechos que inquietan la memoria instituida del país. En otras palabras, la operación rizomática realizada por Zúñiga en su novela nos muestra que hay siempre una distancia insalvable entre los hechos y sus representaciones, entre los acontecimientos y el silencio que les impone cómodamente la historia. De ahí la importancia de "hacer rizoma", de abrir y conectar distintos acontecimientos en el marco de una ficción literaria que traza otra historia y, por ende, otra memoria como efecto de ligar hechos y acontecimientos lejanos en el tiempo. En resumen se entiende que: "lo real debe ser ficcionado para ser pensado" (Rancière 60-61).

Se ha mencionado ya que el relato cuenta con al menos dos narradores, el primero es omnisciente y focaliza los acontecimientos desde la perspectiva de Torres Leiva. El segundo asume la primera persona y corresponde a las intervenciones de García. ¿Por qué motivo el montaje de la novela incluye dos narradores? Una respuesta plausible es la necesidad de poner en tensión la mirada totalizadora de un narrador y la mirada parcial del otro, tensión que hace bascular la pretensión de verdad del lenguaje lógico. En este sentido, la desterritorialización se da en el plano del lenguaje, así, citando a Deleuze (1996): “Cuando la lengua está tan tensada que se pone a balbucir o a susurrar, farfullar..., todo el lenguaje alcanza el límite que dibuja su exterior y se confronta al silencio. Cuando la lengua está tensada de este modo, el lenguaje soporta una presión que lo remite al silencio" ("Balbució" 179). Así, nos podemos preguntar: ¿frente a qué hechos la lengua puede sufrir una presión tal que no haya palabras para narrarlos? Este es el caso de los acontecimientos de la nove- 
la. Se trata de acciones violentas, inenarrables, que provocan perplejidad e impotencia. Ante tales hechos, no solo Torres Leiva no logra balbucear, sino que incluso el narrador que da cuenta de las experiencias traumáticas enfrentadas por el sujeto que es centro del relato, enmudece. La incapacidad de encontrar formas para expresar dichas situaciones, la mudez que se apodera del sujeto narrado y también del narrador, requiere de una voz que soporte el horror y por ello, esté habilitado para contarlo. Esta función la cumple García, el periodista. Torres Leiva calla, García cuenta. El narrador principal también calla ante algunos hechos, y le asigna la tarea de contar al segundo sujeto, a este narrador en primera persona.

Torres Leiva es un sujeto sin voz, cuya palabra no tiene fuerza: “Todos le piden detalles y él habla, pero nunca parece ser suficiente. Nunca lo ha sido, tampoco” (Zúñiga 73). Por ello, se oculta tras la cámara, es un testigo que no tiene agencia: "Pero le llegó la cámara y decidió esconderse tras ella: fotografiar todo lo que pudiera, encerrarse en esas pocas imágenes que lograba revelar" (73; cursiva agregada). La causa de tal rasgo podría encontrase en su historia de vida, en su infancia y en su fracasado matrimonio, pues el protagonista es un ser sin familia. El suyo es un padre ausente. Él y su madre parecen vivir un tiempo de errancia y desarraigo: "Luego vivieron un buen rato como allegados en distintas casas y no podían -o no debían- llevar más de lo necesario" (75). Sobre la madre también se sabe que ha muerto, aunque no se indique cuándo, ni la causa, ni la edad de Torres Leiva en el momento del deceso. De su vida marital, el narrador solo informa que tiene un hijo y menciona una hija que, sin precisarlo, sugiere que ha muerto. La narración alude también a un secuestro del que el protagonista habría sido víctima en su infancia, sin que se entregue mayor información. Todo ello aparece consignado en la novela, es información que surge como lo hacen las líneas de fuga, que son seguidas por el relato hasta que emerge una nueva.

El protagonista es presentado como un individuo solitario. Vive allegado en la casa de una tía en Santiago antes de trasladarse a Iquique, y regresa allí cuando abandona el norte de Chile. No ha logrado el éxito profesional ni económico; no es un individuo de acción. Fotógrafo de bodas y bautizos, estampa en imágenes parejas y familias felices: "fotos donde todo el mundo sonríe, extasiado, y él trata de convertirse en un fantasma capaz de retratar tanta felicidad junta, tanta alegría desbordada" (65); estado del cual él se halla al margen y del que, al parecer, regularmente se vio excluido. Durante su estadía en el desierto, Torres Leiva se 
comporta como los sujetos que describe Waldman en su artículo: "metáfora del carácter dislocado del sujeto de fin de siglo y de su forma de estar en el mundo: nómade, foráneo, descentrado, desplazado y trágicamente desolado." (60; cursiva agregada).

Torres Leiva es un sujeto que vacila, de él se dice que piensa en hacer o decir algo, pero que "no hace nada" (Zúñiga 22). Pese a que ha sido testigo, no logra testificar, permanece en silencio. Él ha decidido para sí un rol invisible: "Es probable que por eso, cuando tenía catorce, decidió cubrirse la cara con esa Canon AE-1 que le regaló uno de sus tíos para navidad" (73; cursiva agregada). En síntesis, el fotógrafo que llega a Iquique es ya un sujeto sin voz, debido a las experiencias dolorosas que solo son aludidas por el narrador, como una de las muchas líneas de fuga. Pero ello solo es sugerido, no es ofrecido como una interpretación que explique la perplejidad y el silencio del protagonista.

En contraste, García difiere de Torres Leiva en muchos aspectos. El periodista es presentado como un sujeto de acciones y palabras intencionadas, que ha consolidado una relación de pareja y una familia estable; cumple con su rol de proveedor, aspira y alcanza éxito, es competente y competitivo. Es retratado también como un ser que no se interesa sinceramente por las personas y sus conflictos. Sin embargo, o justamente por su indiferencia ante el dolor ajeno, es él y quien puede entregar información sobre la violencia soterrada y manifiesta que agobia la zona. El relato de García, por ejemplo, revela que en el área funciona una fábrica de bombas de racimo:

Las bombas se hacían durante el día en aquella fábrica, y luego, durante la noche, distintos camiones atravesaban esos pequeños campamentos que conformaban Alto Hospicio, para luego bajar y cruzar Iquique, cuando todos dormían, hasta llegar al puerto y enviarlas a Irak y a otros países que estaban en guerra. (116-117)

Los camiones que cruzan la ciudad portando las bombas constituyen la amenaza diaria y constante para Iquique. "Pero si un día uno de esos camiones chocaba, si un día alguno de esos conductores se quedaba dormido y volcaba, la ciudad hubiese desaparecido completamente. La imagen de una explosión envolviendo el lugar, las bombas esparciéndose por la ciudad, en todas las direcciones posibles, incontrolables" (117; cursiva agregada), precisa García, sin emitir juicio. Los habitantes de Iquique optan por desviar la mirada, puesto que "aquella empresa le daba trabajo a muchos iquiqueños, aquella empresa era vital para la economía del lugar” (117). 
De allí que el artículo de González y Candia-Cáceres ilumine la lectura de estas citas: el desierto. Alto Hospicio e Iquique son zonas que sufren las consecuencias de un desarrollo acelerado que genera espacios en los que es posible encontrar "fábricas pestilentes, sujetos a la deriva dentro de sus propios orígenes y pueblos de espaldas a cualquier atisbo de cambio que pueda llegar desde las metrópoli" (80). La única vía para hacer frente al empobrecimiento es aceptar trabajar, pese a las condiciones de riesgo, en la fábrica de bombas de racimo. Cabe señalar en este punto que la forma en que se grafica el hipotético accidente, remite al efecto rizomático que provocaría la explosión de las bombas, al envolver la ciudad en una catástrofe incontrolable, en fuego fuera de quicio o sin centro.

El periodista escribe un libro; por ello, es él quien da detalles al protagonista de las desapariciones de Alto Hospicio. De hecho, el capítulo II corresponde íntegramente a la narración de este sujeto sobre el caso, en el cual está visiblemente interesado, pues ve en estos hechos el oportuno material para su reportaje. Se trata, entonces, del sujeto habilitado por el relato para contar el horror. No le afecta la violencia de la que es testigo, solo se interesa en ella por los réditos que le pueda proporcionar. En ese sentido, su intención no es tanto indagar en las múltiples aristas del caso de las desaparecidas, sino en una suerte de apoderamiento de los hechos, busca producir un efecto de verdad, dándole un orden a los hechos, como si orden fuese objetivo o estuviese más allá de la ficción. En efecto, tal es la pretensión de la información periodística, reproducir los hechos al espectador o lector pasivo "tal como son", entregando la verdad predigerida de los hechos en un montaje, en una disposición de los acontecimientos que se dictamina arbitrariamente como el más valedero. Para Jacques Rancière (2000), a esta forma de construir verdad y, con ello, opinión, se oponen los medios del arte y la ficción, concentrados en arrancar los acontecimientos de esa disposición lógica (en una herencia que remonta hasta Aristóteles) en la que reposan en aparente evidencia (57).

\section{La trama horadada}

En este análisis, las líneas de fuga corresponden a aquellos enlaces entre los acontecimientos de la trama y otros referentes históricos, aparentemente desvinculados de la acción central. Como lo plantean Deleuze y Guattari (2004), "hay ruptura en el rizoma cada vez que de las líneas segmentarias surge bruscamente una línea de fuga, que también forma parte 
del rizoma" (15). En otras palabras, se deja ver que el relato no sigue una única línea narrativa cuando incorpora varias voces que enuncian junto a la principal, y cuando presenta líneas de fuga que enlazan lo narrado con otros hechos ocurridos y no consignados por la historia o versión oficial. Entonces las líneas de fuga, contadas por el sujeto habilitado para narrarlas -García como ya se explicitó- permiten dar un vuelco radical a la trama central desarrollada.

La primera línea de fuga introduce a una vidente relacionada con casos de detenidos desaparecidos durante el régimen militar. Doña Emilia, la "vidente", surge en la novela como la sujeto que podría entregar información sobre una de las niñas desaparecidas, Constanza. Sin embargo, el relato la relaciona a su vez con el caso de Freddy Taberna ${ }^{2}$, uno de los primeros militantes socialistas asesinados por la dictadura. A la vez, también sugiere la detención y asesinato de Taberna a manos de los militares, cuyo cuerpo nunca fue encontrado, ni en la ficción novelesca ni en la realidad: "Dicen que a la mañana siguiente de que lo ejecutaran, doña Emilia fue a la casa de los padres de Freddy y les dijo que había soñado con él, que lo vio en el mar, nadando, que no sabía exactamente qué lugar era, pero lo vio nadando mar adentro, sin mirar nunca hacia la orilla." (Zúñiga 132).

Como se aprecia, la inclusión del personaje relaciona la trama central de la novela con otros hechos de desaparecidos en Iquique ${ }^{3}$. El mar, analizado más adelante, es representado como tumba de los detenidos desaparecidos.

Una segunda línea de fuga la constituye la tabla de ouija que vincula la acción principal con el caso de los muertos por la explosión accidental de la fábrica de armas, emplazada en Alto Hospicio. Las parientas de dos de las desaparecidas, también niñas, convocando ánimas para saber del paradero de sus familiares, toman contacto con el espíritu de un obrero que no sabe cómo murió, pero que luego deletrea la palabra racimo. El acontecimiento -también con un referente histórico- se yuxtapone a la trama central; la línea de fuga se dirige esta vez hacia el accidente y las muertes de obreros cuyos cadáveres quedaron esparcidos y destrozados

\footnotetext{
Freddy Marcelo Taberna Gallegos, militante socialista, Director de la Oficina Regional de Planificación durante el gobierno de Salvador Allende, se presentó voluntariamente el día 16 de septiembre de 1973 en el Regimiento de Telecomunicaciones. Fue ejecutado el 30 de octubre de 1973. Su cuerpo no ha sido hallado. (Proyecto Internacional de Derechos Humanos).

El Norte Grande de Chile, lugar en que se emplaza Iquique, fue uno de los lugares elegidos por la dictadura para relegar a los disidentes políticos, así como para ejecutar a los detenidos, cuyos cadáveres fueron enterrados en el desierto.
} 
en el desierto en $1986^{4}$. Resulta plausible imaginar que los restos humanos quedaron esparcidos en el desierto; que en la inmensidad de ese espacio liso quedaron dispuestos los cuerpos desmembrados por efecto del racimo, dando lugar, esta vez, a un rizoma cargado de muerte y horror.

La narración de García, consignada en el segundo capítulo, intenta explicar a Torres Leiva las desapariciones de las jóvenes. Es su voz la que cuenta los acontecimientos anteriores, que en este trabajo son considerados líneas de fuga. Sin embargo, la novela incorpora una nueva figura que aporta al relato otro enigma en torno a las niñas secuestradas. Se trata del testimonio del "loco Martínez" quien, al hablar con el periodista sobre "las fiestas en la casa de los Biaggini, allá en el rancho La Ponderosa” (142), aporta otra arista al caso policial. El testimonio de Martínez, entregado a través del estilo indirecto libre, va adquiriendo progresivamente mayor protagonismo al tiempo que el hecho relatado alcanza mayor grado de escabrosidad. Se construye así una tercera línea de fuga que vincula las desapariciones de las niñas con figuras poderosas del ámbito político militar chileno: "Alguien contó una vez que fue uno de los hijos de Pinochet y que la fiesta se alargó por varios días, hasta que su padre llegó a Iquique y lo mandó a llamar" (142). El relato da cuenta de que "llegaban uniformados que pasaban todo el fin de semana en el rancho" (142). En este contexto es que son mencionadas las niñas: “[P]ero esa noche estaban esos hombres y las mujeres ya no eran las mujeres, no, García, eran pequeñas y tenían esos ojitos rojos, pequeños, tan verdaderos que daba miedo mirarlos por mucho rato, pero los hombres las acompañaron esa noche a todos lados." (143). En esta parte, son dos voces las que relatan, una narración dentro de otra, con el objetivo de que el testimonio del loco Martínez pueda ser incluido en la novela, sin que intervenga la voz del inicio, que en el segundo capítulo sigue muda. Esta situación se conecta con el siguiente punto de intercepción rizomática.

En el último capítulo de la novela se entrega nueva información respecto del hecho policial que es posible identificar como una cuarta línea de fuga, diez años después de resuelto el caso. Una joven más ha sobrevivido y revela que tras los secuestros hay una red de prostitución infantil de la que pudo escapar. Sobre el punto, García discute con Torres Leiva y le recuerda: "era más raro que cerraran el caso con un culpable. Tú estabas

El 25 de enero de 1986 mueren, producto de una explosión, 29 obreros de la fábrica de bombas de racimo de las industrias CARDOEN S.A. (Archivo Vicaría de la Solidaridad). 
ahí, ¿no te acuerdas? ¿Cómo era posible que ese pobre huevón matara a todas esas mujeres durante tantos años, sin que nadie lo supiera?" (226). El testimonio de la joven da cuenta del negocio de trata y prostitución de niñas entre las zonas del Norte grande de Chile y los países fronterizos, es decir, Perú y Bolivia. El testimonio de Camila, antes Constanza, contradice la versión oficial, que habría constatado la muerte de todas las mujeres secuestradas por el violador y asesino en serie, salvo la primera adolescente, Ximena, que permite la aparente solución del caso.

\section{Imaginarios del horror: el mar y la fuerza telúrica}

En la introducción al libro Lo imaginario de Gilbert Durand (2000), Wunnenburger precisa el objetivo de las antropologías que estudian las representaciones imaginales, señalando que "es constante y doble: por una parte, reconstruir la unidad y la coherencia de los imaginarios culturales, reanudándolos a universales simbólicos; por otra parte, retomar el trabajo de diferenciación de las imágenes, sus variaciones geográficas e históricas" (11). En tal sentido, es posible abordar el Océano Pacífico configurado en el imaginario de los chilenos como "ese mar que tranquilo" baña las costas del territorio nacional y contrastarlo con otras "imágenes mentales" que se han construido en torno al mar chileno, pues el océano también connota muerte. En el caso de Chile, es tumba de los detenidos desaparecidos de la dictadura cívico-militar, liderada por el General Pinochet.

El mar chileno constituye, asimismo, una constante amenaza de destrucción total, de muerte y de la consecuente pérdida definitiva de toda memoria. Lo imaginario, propone Wunnenburger, "es un mundo intermediario, vuelto de un lado hacia las estructuras elementales [...] y por otro hacia expresiones singulares, polaridades, y 'cuencas' semánticas”. (11-12). Por lo mismo, es posible establecer un contrapunto entre la imagen del Pacífico cantado, incluso en el himno nacional de Chile, con el imaginario propuesto por la novela, que recoge tanto esta idealización del océano como sus aspectos más oscuros y aterradores, problematizados a lo largo de todo el relato.

Torres Leiva es quien condensa el conflicto entre ambas imágenes del Pacífico, la idealizada y la ominosa: "Recuerda una, sobre todo; su madre y su padre, una playa, el sol que empezaba a esconderse, ellos en la orilla. Una playa sin nombre en un lugar sin nombre. Solo ellos tres [...] No 
sabe qué edad tenía, pero piensa que era un niño por sus padres, porque estaban ahí, en la orilla, juntos, entrando al mar" (Zúñiga 48-49). En esta memoria se lee nostalgia de un tiempo pasado y feliz. Pero el recuerdo anterior contrasta con otros imaginarios del mar que enfrentan a Torres Leiva con el horror. El más claro se halla en el mencionado reencuentro entre él y García, diez años después de los hechos narrados. Revisando el libro que el periodista publicó sobre el secuestro y los crímenes, se consigna entre sus reportajes al "campeón de caza submarina que vio cuerpos en el mar en los ochenta" (212), cadáveres que recuerdan a Taberna y a los desaparecidos arrojados al mar en dictadura ${ }^{5}$, detalle que constituye la quinta línea de fuga, a la que se aludirá brevemente.

La imagen de la ola gigante surge en varias ocasiones. El narrador omnisciente da cuenta de la abundante señalética en Iquique para guiar a las personas en el caso de un eventual tsunami: "una de esas señaléticas antiguas, verdes, con la imagen de una ola" (53). La amenaza constante de un maremoto que arrase todo es insinuada también en el libro que ha publicado García. Torres Leiva busca una foto específica:

Ahí está: una ballena jorobada en Playa Brava. La primera foto la muestra en el mar, todavía, cuando se acercaba a la orilla. En la segunda foto ya está varada, la gente a su alrededor. La tercera foto es el mar rojo, una ola grande, que revienta tras la ballena, una ola completamente roja. (212; cursiva agregada)

La ola roja simboliza tanto el mar que es tumba de cadáveres, como el inminente peligro anunciado por la sangre mezclada con el mar. El relato no se detiene a explicar el hecho, solo lo consigna como una de las tantas líneas de fuga en una imagen cargada de sentido, "no una imagen justa, [sino] justo una imagen". (Deleuze y Parnet 13).

No obstante, el más claro ejemplo del terror que es capaz de infundir en los habitantes la amenaza constate de destrucción es el simulacro de tsumani, que Torres Leiva vive como si se tratara de una real alerta de maremoto: "Ana se asusta. Leonor tirita. Torres Leiva piensa en el departamento de Ana, en cómo el mar va a inundar todo. Avanza y piensa que eso que los rodea va a ser destruido por el mar" (Zúñiga 174). Mientras

Esta práctica podría incluso referirse a un pasado anterior a la última dictadura militar, a pesar de que en la novela se aluda directamente a los ochenta. De hecho, situándonos más atrás, hay un mito donde se afirma que Ibáñez del campo lanzó los cuerpos de los homosexuales al mar. Además, esta vez ya no como mito, Ibáñez también hizo desaparecer cuerpos en el norte, en Pisagua, relativamente cerca de Iquique, mismo emplazamiento que se usó durante la dictadura del general Pinochet. 
carga a Leonor -la hija de Ana, una niña de cinco años-, su determinación radical es no desampararla: "el mar se va a salir, el mar ya se salió, el mar se los va a llevar a todos. Pero él no va a soltar a Leonor, no la va a soltar, aunque la ola los golpee y los arrastre, él no la va a soltar, piensa $^{6 "}$ (175). El terror de Torres Leiva se convierte en desconcierto cuando escucha los aplausos y las felicitaciones de los militares por el éxito del operativo de simulacro. Pese a ello, la amenaza de la ola establece ese contraste necesario con la idílica imagen del Pacífico que "tranquilo" baña las costas chilenas.

\section{Conclusiones}

No hay héroes en esta novela. Ni héroes, ni clímax. Ni justicia, ni verdad. Los cuerpos de los personajes femeninos son, quizás, los depositarios de la lucha contra la impunidad, el olvido y la injusticia. Pese a ello, el resultado de su empeño y obstinación, que parece ser satisfecho con la detención y condena del asesino, es desmentido en los dos últimos capítulos. Frente a la acción decidida de madres, primas y abuelas, las figuras masculinas fluctúan, van desde el desconcierto y la inmovilidad hasta la gestión interesada en la obtención de beneficios personales. El protagonista corresponde al segundo tipo de subjetividad y eventualmente representa en gran medida a la comunidad de esas zonas del desierto, y quizá la alegoría alcance a toda la ciudadanía chilena. En el tercer grupo encontramos una mayor variedad de sujetos: el periodista García que busca publicar un libro sobre el caso y obtener prestigio y beneficios económicos; y, el político Soria ${ }^{7}$-nombre extraído de la política chilena, de quien Zúñiga toma incluso su identidades real-, a los que vemos actuar con el fin de obtener reconocimiento público. En la vereda opuesta a estos sujetos oportunistas y a la inmovilidad de Torres Leiva, se encuentran las jóvenes víctimas del secuestro y la violación, las muchachas asesinadas o utilizadas en la trata de blancas. La precariedad en que están inmersas se explica pues en nuestros tiempos "[1] a persona humana tiende a desaparecer como persona de derecho, puesto que es negociada en tanto poseedora de órganos comerciables" (Kristeva 18). Junto a ellas aparecen las madres, primas y abuelas que

\footnotetext{
Este pasaje podría aludir al trauma que acarrea el personaje, pues como anteriormente se ha señalado, el relato alude tangencialmente a una hija muerta.

Jorge Alejandro Soria Quiroga, alcalde de Iquique en los periodos: 1964-1973, 1992-2007 y 2012-2016.
} 
persisten en su demanda de justicia y, de manera incansable, mantienen la búsqueda de las jóvenes desaparecidas.

Racimo no intenta ficcionalizar un hecho histórico simplemente, pues los acontecimientos narrados no responden "a un punto de vista fijo, exterior a lo reproducido" (Deleuze y Guattari 377). El narrador principal parece seguir variados hilos narrativos para urdir la trama de su ficción:

[S] eguir es algo totalmente distinto que el ideal de reproducción. [...] Uno está obligado a seguir cuando está a la búsqueda de las 'singularidades' de una materia. O más bien de un material, y no tratando de descubrir una forma; [...] cuando deja de contemplar el flujo laminar con una dirección determinada, y es arrastrado por un flujo turbulento; cuando se aventura en la variación continua de las variables, en lugar de extraer de ellas constantes. (377)

La narración en Racimo opera siguiendo las variadas líneas de fuga que interceptan el hecho principal y lo ponen en estado de variación continua. Deleuze y Guattari (2004) precisan que “[e]n un rizoma hay solo líneas" (14). Racimo, como un rizoma, no sigue un orden de causa y efecto, sino que establece conexiones que se entrecruzan y yuxtaponen: "el rizoma conecta cualquier punto con otro punto cualquiera, cada uno de sus rasgos no remite necesariamente a rasgos de la misma naturaleza" (25). En el caso de los delitos y crímenes sobre los que narra la novela, "el libro no es una imagen del mundo [...]. Hace rizoma con el mundo, hay una evolución aparalela del libro y del mundo" (16). En otras palabras, la ficción novelesca es un rizoma que establece líneas de fuga con la historia de los crímenes de Alto Hospicio y con otros casos similares -pero no del mismo origen- de desapariciones y muertes ocurridas en Chile, mencionadas en el relato y en conexión con acontecimientos históricos como referentes. $\mathrm{Si}$ “[e]l rizoma está relacionado con un mapa que debe ser producido, construido, siempre desmontable, conectable, alterable, modificable, con múltiples entradas y salidas, con sus líneas de fuga" (25), Racimo funciona como rizoma cuando vincula dimensiones que surgen sorpresivamente, que van marcando caminos en el mapa que se va construyendo a medida que se relatan los acontecimientos. La narración así "[n]o tiene principio ni fin, siempre tiene un medio por el que crece y desborda" (25). 
En cuanto a la desterritorialización de los relatos históricos, de las verdades instauradas o los procesos judiciales cerrados, la novela ofrece otra versión de la resolución de los crímenes, discutiendo así la que se entregó oficialmente, tanto en la novela como en el acontecimiento histórico que inspira la trama. Ambos discursos, el de la ficción y el de la resolución judicial del caso, coinciden en su versión oficial con la detención y condena del imputado; en Racimo corresponde a Miguel Ángel Solís; por su parte, en el mundo real, la justicia chilena condenó a Julio Pérez Silva a 42 años de presidio. En suma, la novela ficcionaliza los hechos, no los altera ni los encubre, sino que los dispone en un nuevo e inusitado orden que contesta el orden naturalizado de la verdad oficial (Rancière 6o-62). Así, la novela de Zúñiga ha recogido los rumores y las voces que apuntan a la trata de niñas en una red de prostitución infantil de carácter internacional. Entonces, lo singular de la novela rizomática es resistir al peso de la historia, a su gesto autoritario, para invitar al lector a construir otra memoria en el acto de conectar distintos acontecimientos del pasado reciente. En este punto, resulta válido recordar que el narrador, en un intento vano, adelanta acontecimientos, como si fuera posible obstruir las líneas de fuga que, sin embargo, desbordan el relato.

Iquique y Alto Hospicio, las jóvenes desaparecidas en el desierto, los relatos que emergen de improviso y que no siguen un desarrollo causal sino uno rizomático, son características que ya aparecían en Camanchaca (2015), la primera de Zúñiga: "Su nieta está desaparecida. Su nieta, según ella, algún día va a regresar. De eso está segura, por eso no cree en la historia del psicópata de Alto Hospicio. Ese hombre es inocente, me dice ella, ese hombre está pagando por otra cosa." (83).

El curso del rizoma parece saltar desde este primer relato a Racimo. En el desenlace se menciona otras muertes, otros casos olvidados que oculta el desierto: “Cierro los ojos. Y los veo en la carretera, ahí, tendidos en la carretera. Los cuerpos. Niños y viejos. En mitad de la carretera. Los veo en mitad del desierto y mi papá los esquiva, acelera y los esquiva" (Camanchaca 120; cursiva agregada). Metáfora del rápido proceso de modernización industrial al que alude el estudio de González y CandiaCáceres, el padre del narrador protagonista evita esos cadáveres que su hijo no deja de ver, como la herencia de muerte que la generación anterior ha legado a su descendencia.

Son muchas más las líneas de fugas que ofrece la novela. Quedan sin analizar la caída de las Torres Gemelas, hecho histórico que coincide con 
el inicio de la trama; la virgen de Alto Hospicio que llora sangre; la trata de niñas en el negocio de la prostitución y los intereses políticos involucrados en los hechos, por nombrar solo algunos. Los múltiples senderos abordados y por abordar que atraviesan el relato, permiten comprender que la novela Racimo de Diego Zúñiga funciona como rizoma, que la relación racimo-rizoma va más allá de un juego de palabras, que la aliteración propuesta puede ser intencionada.

\section{Referencias bibliográficas}

Archivo Vicaría de la Solidaridad. "Muerte de 20 obreros por explosión en la fábrica de armamentos 'Cardoen' de Iquique”. ArchivoVicaría. cl. Sala virtual. Recuperado de http://archivovicaria.cl/ archivos/VS4cb713ba86de3 14102010 1129am.pdf.

Deleuze, Gilles. “Balbució”. Crítica y Clínica. Barcelona, Anagrama, 1996.

Deleuze, Gilles y Félix Guattari. Mil mesetas. Capitalismo y esquizofrenia. Sexta edición. Valencia, Pre-textos, 2004.

Deleuze, Gilles y Claire Parnet. Diálogos. Primera edición. Valencia, Pretextos, 1980.

González Daniuska, Candia-Cáceres, Alexis. “Geografías invisibles de la globalización: Bolaño, Almada y Zúñiga”. Anales de Literatura Chilena, no. 28, diciembre 2017, pp. 79-94.

Kristeva, Julia. Sentido y sinsentido de la rebeldía. Santiago, Cuarto Propio, 1999.

Landaeta, Patricio. "Gilles Deleuze y Jacques Rancière. Arte, montaje y acontecimiento". Estudios de Filosofía, vol. 13, 2014, pp. 173-183.

Proyecto Internacional de Derechos Humanos. "Freddy Marcelo Taberna Gallegos”. Memoriaviva.com. 1996- 2015. Recuperado de http://www.memoriaviva.com/Ejecutados/Ejecutados T/ taberna gallegos freddy marcelo.htm.

Rancière, Jacques. Le partage du sensible. Esthétique et politique. París, La Fabrique, 2000.

Rodríguez, Fermín. “Cuerpo y capitalismo. El trabajo de la violencia y el miedo”. Estrategias. Psicoanálisis y salud mental, no. 4, año 3, 2016, pp. 43-46. 
Waldman Mitnick, Gilda. "Reflexiones (y una breve travesía literaria) por los desiertos de la frontera norte de Chile y México". Caderno de letras, no. 27, Jul-Dez. 2016, pp. 49-72.

Wunenburger, Jean-Jacques. "Introducción. Lo imaginario de Gilbert Durand”. Lo imaginario por Durand, Gilbert. Barcelona, Ediciones del Bronce, 2000.

Zúñiga, Diego. Camanchaca. 2012. Santiago, Literatura Random House, 2015.

Racimo. Santiago, Literatura Random House, 2014. 